\title{
Developing a typology for social infrastructure (Case study: Road side station infrastructure)
}

\author{
Herawati Zetha Rahman ${ }^{1 *}$, Azaria Andreas ${ }^{1}$, Dian Perwitasari ${ }^{1}$, and Jade Sjafrecia \\ Petroceany $^{1}$ \\ ${ }^{1}$ Department of Civil Engineering, Universitas Pancasila, Jakarta Selatan, Indonesia
}

\begin{abstract}
At this time, the concept of Social Infrastructure has been studied in Indonesia. One of many types of this kind of infrastructure is called Roadside Station, adopted from Japanese Michinoeki. A roadside station is a place located at the side of the national road in a backbone of Strategic Development Area. This place organizes service functions to road users, economic empowerment of the local community, and part of incubation service for its surrounding area. The concept of the roadside station that will be applied is developing a place for resting around the national road. There will be many public facilities in this roadside station such as a parking place, toilet, restaurant, and retail market. Ideally, this public facilities will be managed by the local community. This research is aim to develop roadside station typologies based on predefined criteria. The first things to do is doing benchmark analysis related to management concept plan for the roadside station. The benchmark is from management concept for the rest area's highway. The next thing, for each typology, will be defined as the most suitable financial scheme, even it comes from the government fund or from the public-private partnership (PPP). In the end, the research results in determining 3 types of typology for developing roadside station and 3 criteria such as traffic volumes daily, type of zoning according to the location of a roadside station, and type of strategic development area according to the location of the roadside station.
\end{abstract}

\section{Introduction}

The future policy direction of the Ministry of Public Works and Housing of Indonesia in developing infrastructure is based on the Strategic Development Area (SDA) policy by the Regional Infrastructure Development Board. Indonesia divided by 35 SDA spread over five main islands and 33 provinces. The purpose of developing SDA is to reduce the economic disparities between regions, especially between the West and East Indonesia. Therefore it is necessary to accelerate and equitable regional development by emphasizing the competitive advantage of the local economy based on natural resources, human resources, infrastructure provision and technology development. To support this achievement, the Regional Infrastructure Development Board has done several things, one of which is providing

*Corresponding author: zetha.rahman@univpancasila.ac.id 
social-based infrastructure. Social infrastructure is a catalyst that provides a place/ facility to improve the quality of life in a particular community. Some authors, economists, and urban planners have classified infrastructure into 2 type such as physical infrastructure and social infrastructure. Economic infrastructure assists in production functions by lowering production cost and raising the productivity of labor and capital, while social infrastructure helps to improve the efficiency and skills of human resources [1].

One of social infrastructure that provided by the Ministry of Public Works and Housing is Rest Area, but with the name Roadside Station. The Roadside Station is a particular area built as a form of awareness to improve the safety of road users, supported by the development of local communities and information centers. In its physical form, the roadside station is a collection of buildings within an integrated area located on the edge of a national road. The roadside station has various functions such as for a place to rest, where to get information, providing green open areas, educational facilities, providing outlets to promote local products. One of the functions of the existence of a roadside station that improves the economy of the community around the area is expected to be accomplished.

Based on research conducted by Center of Road and Bridge of Ministry of Public Works and Housing, the road users need a rest at least after driving for 4 hours. Generally, riders in big cities take advantage of rest or rest area on the highway which has various supporting facilities such as gas stations, toilets, ATMs, restaurants, outlets, and others. During this time on the national road, the existence of a place to rest is not as complete as the rest area on the highway, except as a place to eat or stalls that have limited facilities on the roadside. This study aims to develop typology of the roadside station to be established in 35 SDA spread across Indonesia. The ondition and characteristics of the existing area in each SDA are different so it needs a separate development of roadside station.

\section{Literature review}

\subsection{Social infrastructure}

Social infrastructure always associated with a government-owned construction with the aim of serving people with specific needs such as educational institutions, health and safety institutions, sports and recreational facilities [2]. In other words, social infrastructure is provided by the government to maintain and improve the standard and quality of life of a community. Social infrastructure can be categorized into 2 type [3] as follows: 1) Hard Infrastructure. They include health center facilities, education (schools, museums, libraries), recreation areas, police and fire stations, correctional institutions, rest areas, and other supporting facilities. 2) Soft Infrastructure. In the form of programs, policies with the aim to improve the quality and standard of living of a community. The role of social infrastructure in an area include: 1) Encourage the participation of the local community; 2) Support communities from different backgrounds; 3) Creating a sustainable community; 4) Improve the level of health; 5) Supporting the emerging community; 6) Improve the community's economy.

\subsection{Michinoeki}

The concept of a roadside station was adopted from Michinoeki from Japan. In the early 1990 's, the Japanese government conducted a social experiment to provide service to road users. The research is a unique concept because it seeks to create strong links between road users and local communities in the form of roadside facilities. The experiment proceeded successfully and was later named Michinoeki. 


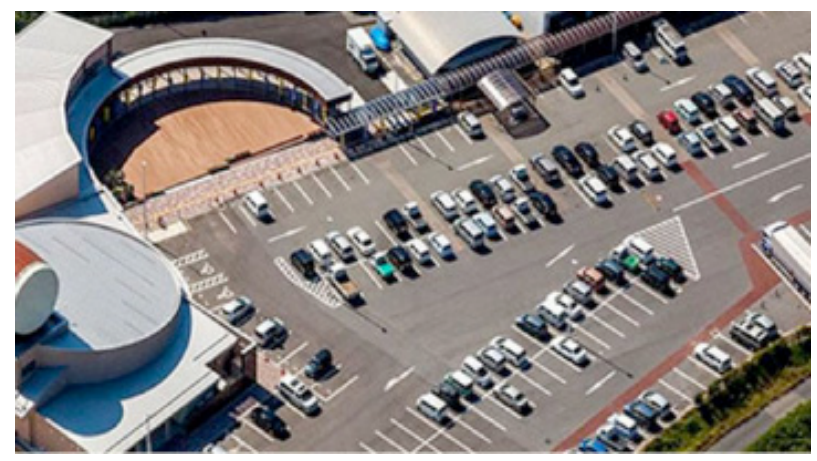

Fig. 1. One example of Michinoeki in Japan [7].

Michinoeki has the meaning of a road service platform and has been implemented in Japan since 1993 [4]. Michinoeki was developed to create safe travel traffic while creating a unique and lively space to promote the potential of the area around the michinoeki location. Since then, Michinoeki has entered into the state law and has been widely developed until there are already about 1093 michinoeki facilities scattered throughout Japan in 2016 [5].

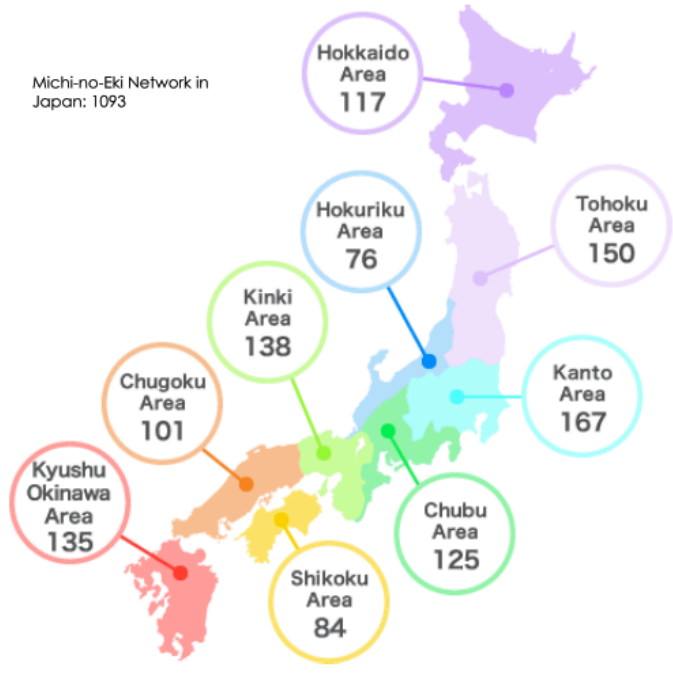

Fig. 2. The distribution of Michinoeki in Japan by 2016 [7].

Michinoeki has three basic functions, such as providing a place to rest, providing information, and linkage with the surrounding area. Michinoeki in Japan provides full 24hours access to restrooms and parking lots. In some regions, Michinoeki has restaurant facilities, shops selling local community productions, parks, museums, and other facilities. Michinoeki also provides tourist information for domestic and foreign tourists, medical information, museums, and mini-libraries to introduce local history and culture.

Michinoeki is a facility that drives the income of regional communities in the form of employment. The concept of Michinoeki began to be adopted in Thailand in 2006 [6], then in the UK in 2010 [7] and then spreading to other countries. In Indonesia, the concept of Michinoeki is known under the name of the Roadside Station, developed by Center of Road and Bridge of Ministry of Public Works and Housing in 2015. 


\subsection{Strategic development areas}

To support the strategic objectives of Ministry of Public Works and Housing, the planning and programming of infrastructure development are doing through the regional approach as outlined in 35 Strategic Development Areas (SDA) or Wilayah Pengembangan Strategis (WPS) that can be seen in the figure below. SDA based development is an approach that combines market development with market-driven, taking into account economic, social and environmental aspects to support the implementation of sustainable infrastructure development.
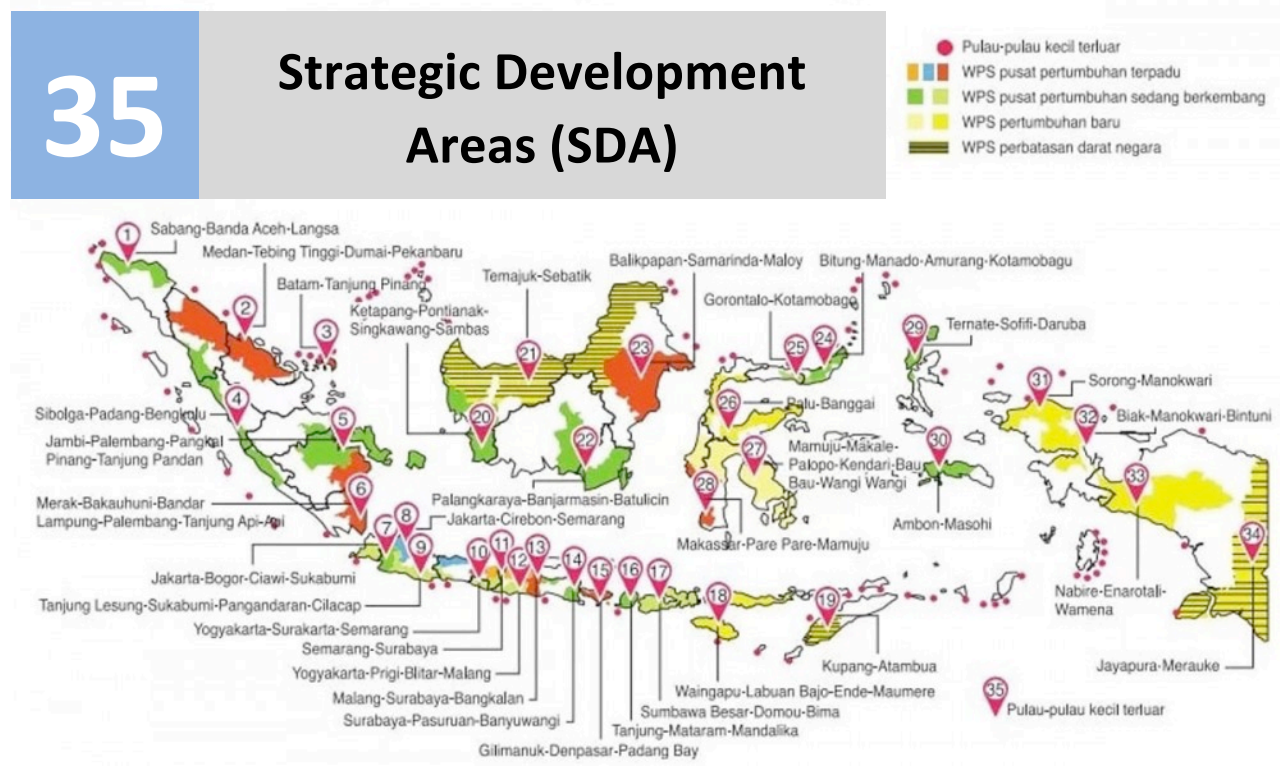

Fig. 3. 35 Strategic development areas in Indonesia [8].

\subsection{Roadside Station}

The provision of rest areas is a must to ensure the comfort and safety of road users for long-distance travel following Road Traffic and Transportation regulation No. 22 the year 2009.

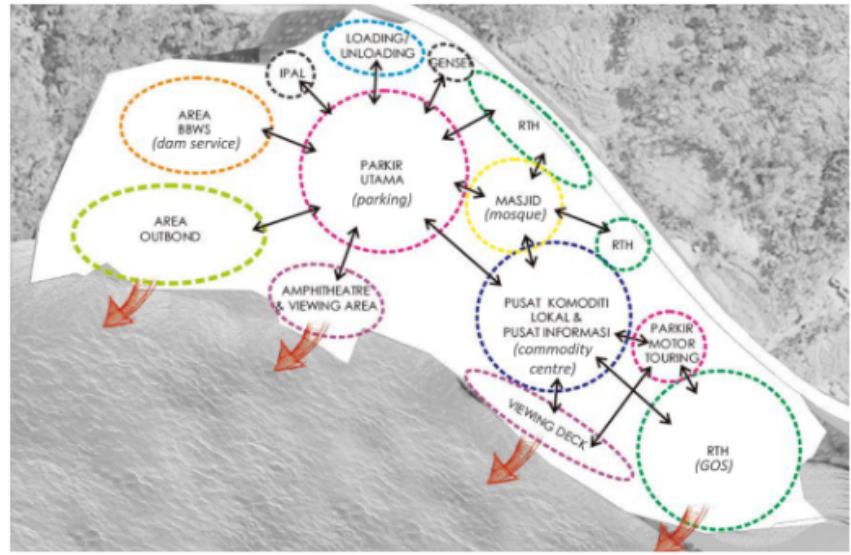


Fig. 4. Roadside station located in Trenggalek [8].

The primary function of the roadside station is to provide a resting place that can enhance the economic development of the area and increase the value of road infrastructure [8]. The roadside station in Trenggalek is seen in Fig. 4.

In addition to functioning as a place of rest, roadside station also provides an alternative destination to increase the value of infrastructure in the vicinity of the road. The target is done by utilizing the landscape area, location, product diversity, etc. Similar to Michinoeki, the benefits of roadside station development are Empowerment, Incubation Function, Social Welfare, Information Exchange, Knowledge and Commodities, and Driving Security.

Table 1. Roadside station components [8].

\begin{tabular}{|c|c|c|c|}
\hline Main component & Support component & $\begin{array}{l}\text { Additional } \\
\text { component }\end{array}$ & $\begin{array}{l}\text { Limited additiona } \\
\text { component }\end{array}$ \\
\hline $\begin{array}{l}\text { Infrastructure display } \\
\text { facilities around }\end{array}$ & Operational office & Children's playroom & Fuel Station \\
\hline $\begin{array}{l}\text { Information and } \\
\text { communication } \\
\text { facilities }\end{array}$ & Toilet / Bathroom & $\begin{array}{c}\text { Automated Teller } \\
\text { Machine (ATM) }\end{array}$ & $\begin{array}{l}\text { Other facilities as } \\
\text { needed }\end{array}$ \\
\hline $\begin{array}{l}\text { Surrounding products } \\
\text { display }\end{array}$ & Worship place & Multipurpose room & \\
\hline $\begin{array}{c}\text { Tour viewing facilities } \\
\text { around }\end{array}$ & Restaurant / food court & $\begin{array}{l}\text { Local rental space } \\
\text { with national standard }\end{array}$ & \\
\hline $\begin{array}{l}\text { Exhibition facilities } \\
\text { and local cultural } \\
\text { attractions }\end{array}$ & Security & Workshop & \\
\hline \multirow[t]{7}{*}{$\begin{array}{l}\text { Rest and parking } \\
\text { facilities }\end{array}$} & Breastfeeding room & & \\
\hline & $\begin{array}{l}\text { Basic health services } \\
\text { room }\end{array}$ & & \\
\hline & Green open space & & \\
\hline & $\begin{array}{c}\text { Installation of clean } \\
\text { water }\end{array}$ & & \\
\hline & $\begin{array}{l}\text { Waste management } \\
\text { facilities }\end{array}$ & & \\
\hline & $\begin{array}{c}\text { Installation of } \\
\text { wastewater treatment }\end{array}$ & & \\
\hline & $\begin{array}{c}\text { Electricity and energy } \\
\text { facilities }\end{array}$ & & \\
\hline
\end{tabular}

Roadside station components are divided into 4 (four) types such as the main components such as in Table 1, the supporting components, the additional components, and the limited additional components. Principles and elements of architecture on all parts of 
roadside station adapted to its surrounding area with attention to local wisdom. Also, the whole design should pay attention to accessibility for the disabled person.

The roadside station provides the following functions: 1) Intelligent information center with the provision of WIFI, traffic information, and infrastructure information near the roadside station, 2) As a Ministry of Public Works and Housing's infrastructure information center, especially near the location, 3) Information center of various products and potential areas around the site, 4) Stores on a variety of high-tech infrastructure and beautiful place of the surrounding, 5) Introduction and proposing of local community product and culture to national road users, 6) Incubation area for new tourist destinations independently or as part of the leading destination, and, 7) As a rest area to improve the safety of national road users equipped with various service facilities.

\section{Methodology}

This study used a qualitative approach in the following stages:

1) Identified the criteria needed for developing the roadside station typology. Measures were identified with benchmarking analysis done in several types of roadside station planning around the world. The Criteria that proposed in this research then validated in Focus Group Discussion (FGD) between several government agencies under the Ministry of Public Works and Housing.

2) After defining the criteria, next is developing indicator needed to specify the typology. Based on the indicator proposed, the four types of the roadside station is created, and, also, this indicator then validated in FGD between several government agencies under the Ministry of Public Works and Housing.

3) The next is adjusting the criteria and its indicator according to the stakeholder (Ministry of Public Works and Housing, and others) needs to find typology of the roadside station that can be applied under all conditions in Indonesia.

\section{Results and discussion}

Classification of roadside station typology used are based on three criteria:

1) Spatial Planning

In addition to being placed on the national roadside, not all regions are considered necessary to be built the roadside station. Taking into account the principles and functions of the roadside station, the types of areas chosen to be included in the typology criteria including, Industrial Zone (IZ), Tourism Zone (TZ), Agro Zone (AZ), and Trading and Services Zone (TSZ). The basis of the establishment of these areas has received validation and approval in the Focus Group Discussion (FGD) involving several government agencies located under the Ministry of Public Works and Housing.

2) LHR (unit in a vehicle), or also known as Average Daily Traffic (ADT), is a two-way traffic volume through an average point in 1 day which is then calculated throughout the year. LHR is a standard term used in calculating the traffic load on a road segment and is the basis in the transportation planning process. Concerning the roadside station, the national road connecting one city with another city in Indonesia does not have the same LHR value or vehicle volume. It will also relate to the type of facility to be provided at the roadside station. Therefore, national roads with high LHR value will have more complete facilities than national roads with low LHR value. In this research, the LHR classification used issued by Bina Marga (1992). The classification divided by 3 types, Type A (LHR > 10,000 vehicles); Type B (LHR 5,000 < LHR < 10,000 vehicles); and Type C (LHR < 5,000 vehicles). 


\section{3) SDA}

SDA is used as the basis for developing main islands in Indonesia/islands within the same administrative area as well as across districts/ cities and/ or across provinces, encompassing various interconnected areas as areas and priorities of integrated infrastructure development focus. In Indonesia, SDA are grouped into four types, 1) Integrated Growth Center SDA; 2) Center for Growth SDA; 3) New Growth SDA, and 4) Borderline SDA. The reason for the grouping of SDA is because Indonesia's region has an uneven level of economic. With this grouping, it will help the government to identify areas that require more support for the development of the region. Based on these 3 aspects, then 4 types of roadside station typology are developed (Table 2).

The typology of the roadside station may change from time to time following the development of the conditions where the intelligent pavilion is located (changes to national road LHRs and SDA types in roadside station's location). This, however, does not apply to the $4^{\text {th }}$ Type where located in Borderline SDA. According to the typology that has been developed, the components of the roadside station was grouped into 4 (four) types Table 3.

Table 2. Roadside station typology.

\begin{tabular}{|c|c|c|c|c|}
\hline Criteria & 1st type & 2nd type & 3rd type & 4th type (special) \\
\hline \multirow{3}{*}{ Spatial } & $\mathrm{IZ}$ & $\mathrm{IZ}$ & $\mathrm{IZ}$ & $\mathrm{TZ}$ \\
Planning & $\mathrm{TZ}$ & $\mathrm{TZ}$ & $\mathrm{TZ}$ & $\mathrm{AZ}$ \\
& $\mathrm{AZ}$ & $\mathrm{AZ}$ & $\mathrm{AZ}$ & $\mathrm{TSZ}$ \\
& $\mathrm{TSZ}$ & $\mathrm{TSZ}$ & $\mathrm{TSZ}$ & $\mathrm{NA}$ \\
\hline \multirow{2}{*}{ LHR (vehicle) } & $>10.000$ & $5.000-10.000$ & $<5.000$ & Borderline \\
\hline \multirow{2}{*}{ SDA } & Integrated Growth & Center for & New Growth & Growth \\
& Center & \multicolumn{2}{|c}{}
\end{tabular}

Table 3. Roadside station components based on typology.

\begin{tabular}{|c|c|c|c|c|}
\hline Component ANJAS & 1st type & 2nd type & 3rd type & 4th type (special) \\
\hline Main component & $\sqrt{ }$ & $\sqrt{ }$ & $\sqrt{ }$ & $\sqrt{ }$ \\
\hline Support component & $\sqrt{ }$ & $\sqrt{ }$ & $\sqrt{ }$ & $\sqrt{ }$ \\
\hline Additional component & $\sqrt{ }$ & $\sqrt{ }$ & \\
\hline $\begin{array}{c}\text { Limited additional } \\
\text { component }\end{array}$ & $\sqrt{ }$ & & & \\
\hline
\end{tabular}

\section{1 $1^{\text {st }}$ Type roadside station}

The 1st type roadside station is located on a national road on SDA with the category of Integrated Growth with high average daily traffic, which is more than 10,000 LHR. In addition to the main components and supporting components, the 1st type of roadside station allows being equipped with main components, support components, additional components, and limited additional components. Thus in 1st type typology, there is a multiincome probability obtained from additional components and limited additional components. The cost of management can be done by a self-managed private enterprise. 


\section{$4.22^{\text {nd }}$ Type roadside station}

The $2^{\text {nd }}$ type roadside station is located on the national road in SDA with the category of Medium Growth with average daily traffic medium, which is between 5,000 to 10,000 LHR. In addition to the main components and supporting components, the $2^{\text {nd }}$ type of roadside station allows being equipped with main components, support components, and additional components. For this typology is also expected to the inclusion of facilities available on limited additional components.

\section{3 $3^{\text {rd }}$ Type roadside station}

The $3^{\text {rd }}$ type roadside station is located on the national road in SDA with the New Growth category with the average daily traffic of less than 5,000 LHR. For typology, The $3^{\text {rd }}$ type roadside station consists of only the main components, and the supporting components. In other words, this typology is a roadside station with basic functions only and becomes a government obligation in its development.

\section{$4.44^{\text {th }}$ Type roadside station}

The $4^{\text {th }}$ type roadside station is located on the national road in SDA with the category of Borderline. For this typology, daily traffic is not a reference. In general, this typology has a resemblance to the $3^{\text {rd }}$ roadside station's typology. It is because the Borderline SDA are within the New Growth SDA category. For this typology, the roadside station consists of only the main components, and sometimes the supporting elements. In other words, this typology is only a roadside station with essential functions only and becomes a government obligation in its development. But along with the growing of the marginal zone, the 4th type roadside station allows being equipped with additional components. Thus the management of this typology is possible identic with the management of $2^{\text {nd }}$ type typology.

\section{Conclusions}

Construction of the roadside station in Indonesia can refer to 1 of 4 types of typology proposed from this research. Based on the analysis, the four types of typology represent various regional conditions in Indonesia. Since 2015 the Ministry of Public Works and Housing has been built two roadside station located in Jembrana and Trenggalek districts. Both of the roadside stations could be used as a social infrastructure that not only functions as a rest area but also provides alternative destinations that will enhance the value of road infrastructure by utilizing the location, beautiful scenery, diversity of local products, art (including performance) and infrastructure technology. In the future, the development of another roadside station in various other locations in Indonesia can use the proposed typology in this research.

\section{References}

1. A. Kumari, A.K. Sharma, World Development Perspective 5, (2017)

2. K.N. Gabdrakhmanov, A.V. Rubtsov, Proc. Soc. and Behav. Sci. 140 (2014)

3. C. Kingombe, Hard and soft infrastructure in Africa (UNCTAD, Tunisia, 2014)

4. K.H. Murakami, T. Oyabu, J. of Global Tourism Res. 1, 1 (2016) 
5. Ministry of Land, Infrastructure, Transport and Tourism, The 44th Registration of Michinoeki. Available at: http://www.mlit.go.jp/report/press/road01_hh_000570.html (2015)

6. K. Kaneko, Michinoeki- Spreading to Overseas. Available at: http://www.jri.co.jp/page.jsp?id=5963 (2006)

7. G. Parker, Michinoeki: An opportunity for the rural economy? town \& country planning (2010)

8. Kementerian PUPR, Sinergi-Bulletin BPIW 22, (2017) 